\title{
Discrepancies in the in vitro and in vivo role of scavenger receptors in clearance of nanoparticles by Kupffer cells
}

\author{
Guankui Wang, Ernest Groman, and Dmitri Simberg* \\ The Skaggs School of Pharmacy and Pharmaceutical Sciences, University of Colorado Anschutz Medical Campus, \\ 12850 East Montview Blvd., Aurora, CO 80045, USA
}

Submitted: April 16, 2018

Accepted: April 30, 2018

Published May 13, 2018

\section{Abstract}

Nanoparticles are recognized and cleared by Kupffer cells (KCs) in the liver. This process complicates the development of targeted nanoparticles because of significant reduction of number of nanoparticles that can reach target tissues. Macrophage scavenger receptor SR type AI/II is the central phagocytic receptor that has been shown to promote in vitro uptake of many nanoparticle types. In this paper, the authors set out to clarify the role of SR-AI/II in the in vivo liver clearance of $10 \mathrm{kDa}$ dextran superparamagnetic iron oxide (SPIO) Feridex-IV® and 20kDa dextran-coated SPIO nanoworms (SPIO NWs). Feridex showed efficient SR-AI/II-dependent uptake by isolated KCs in vitro, whereas SPIO NWs showed no uptake by KCs. Both Feridex and SPIO NWs showed a very short and nearly identical circulation half-life and efficient uptake by KCs in vivo. The SR-AI/II inhibitor, polyinosinic acid, prolonged the circulation halflife of both Feridex and SPIO NWs, but did not reduce the KC uptake. The circulation half-life and KC uptake of Feridex and SPIO NWs were identical in SR-AI/II-deficient mice and wild-type mice. These data suggest: (1) there is a limited correlation between in vitro and in vivo uptake mechanisms of nanoparticles in KCs; and (2) redundant, SR-AI/II independent mechanisms play a significant role in the nanoparticle recognition by $\mathrm{KCs}$ in vivo. Understanding the complexity of nanoparticle clearance assays and mechanisms is an important step to improving the design of "stealthy" nanoparticles. ${ }^{i}$

\section{Purpose and Rationale}

The goal of the study is to test the role of type SR-AI/II macrophage receptors in the in vivo clearance of iron oxide nanoparticles. The study demonstrates that while in vitro there is a role for scavenger receptor, in vivo there are other mechanisms, too. This result should be important for scientists who attempt to predict mechanisms of nanoparticle immune recognition based on simplified in vitro tests.

\section{Introduction}

Macrophage scavenger receptors (SRs) are a broad group of phagocytic receptors that are responsible for the elimination of blood-borne viruses, pathogens, and various negatively charged ligands in vivo. ${ }^{1}$ The classical SRs type $\mathrm{AI} / \mathrm{II}$ (SR-AI/II) are largely restricted in their expression to macrophages and are highly expressed on liver Kupffer cells (KCs), ${ }^{1}$ which are responsible for clearance of a wide range of nanoparticles. ${ }^{2}$ SR-AI/II recognizes negatively charged surfaces through a positively charged collagen-like domain. ${ }^{3-6}$ Several reports demonstrated that SRs including SR-AI/II are implicated in in vitro uptake of engineered nanoparticles, including polystyrene, ${ }^{4,5}$ quantum dots, ${ }^{7}$ diesel particles, ${ }^{8}$ spherical nucleic acids, ${ }^{9}$ and titania and iron oxide nanoparticles. Dextrancoated superparamagnetic iron oxide nanoparticles (SPIO) are highly effective magnetic resonance imaging (MRI) contrast agents. Feridex (ferumoxides), the first FDA approved SPIO developed as an MRI contrast agent, is coated with $10 \mathrm{kDa}$ linear dextran, and has an average diameter of $100 \mathrm{~nm}$. Dextran SPIO nanoparticles usually consist of several $5-10 \mathrm{~nm}$ $\mathrm{Fe}_{3} \mathrm{O}_{4}$ cores embedded in a meshwork of branched dextran $(10-40 \mathrm{kDa}) . \mathrm{Fe}_{3} \mathrm{O}_{4}$ crystals' slight anionic charge due to the ionization of the hydrated iron oxide surface accounts for the

${ }^{*}$ Corresponding author: dmitri.simberg at ucdenver.edu 
interaction with the SR-AI/II receptors. ${ }^{11} \mathrm{We}$ previously demonstrated that SR-AI/II efficiently recognizes Feridex through interaction between the cationic collagen-like domain of the receptor and the incompletely covered, negatively charged crystalline core. ${ }^{11}$ We also demonstrated that dextran coating plays a critical role in blocking SR-AI/II recognition. Increasing the molecular weight of dextran blocks the receptor binding in vitro. When we synthesized SPIO coated with 20 $\mathrm{kDa}$ dextran (SPIO nanoworms) or conjugated dextran on top of the Feridex's dextran, the recognition by SR-AI/II transfected cells was blocked. $^{11}$ Several reports including ours ${ }^{6,12,13}$ have shown that polyanionic inhibitors of SRs such as polyinosinic acid, fucoidan, and dextran sulfate, could inhibit the uptake of Feridex in vitro.

Feridex is rapidly cleared from systemic circulation by the liver, spleen, and lymph nodes, and has a short half-life of 1-3 hours in humans $6,14,15$ and $10-30$ minutes in mice. ${ }^{14}$ While useful for liver imaging, rapid clearance limits the utility of Feridex and other SPIOs due to their decreased ability to reach diseased tissues including tumors. ${ }^{16}$ These short blood lifetimes underscore the importance of understanding the mechanisms of blood clearance, principally by $\mathrm{KCs}$, in order to improve opportunities to target tissues outside the liver. So far, no studies were reported on the role of SR-AI/II in the in vitro uptake and in in vivo clearance of SPIO by KCs. Here we studied the role of these receptors in the clearance of $10 \mathrm{kDa}$ dextran-coated Feridex and 20kDa dextran-coated SPIO NWs in vivo. Our data demonstrate a stark discrepancy between in vitro and in vivo mechanisms of uptake and suggest that SR-AI/II independent mechanisms mediate the clearance of SPIO NWs and Feridex in vivo. The comparison of cellular uptake in vitro and in vivo may serve as a caution regarding studies involving other nanoparticles.

\section{Materials and Methods}

\section{Materials}

For the synthesis of SPIO, linear dextran (15$25 \mathrm{kDa}$ molecular weight) and iron salts were purchased from Sigma-Aldrich (Saint Louis, MO). Feridex intravenous (I.V.) nanoparticles coated with $10 \mathrm{kDa}(\mathrm{T}-10)$ branched dextran were obtained from AMAG Pharmaceuticals. Polyinosinic acid, heparin, heparan sulfate, and chondroitin sulfate were all from Sigma.

\section{Nanoparticles}

SPIO NWs ${ }^{17,18}$ coated with $20 \mathrm{kDa}$ dextran was prepared by precipitation of $\mathrm{Fe}^{2+}$ and $\mathrm{Fe}^{3+}$ salts in ammonia in the presence of branched dextrans $15-25 \mathrm{kDa}$ (hereafter $20 \mathrm{kDa}$ SPIO) as described elsewhere in the literature. ${ }^{19}$ Particles were resuspended in pyrogen-free water at 1-2 $\mathrm{mg}(\mathrm{Fe}) / \mathrm{mL}$ and filtered through a $0.2-\mu \mathrm{m}$ membrane filter before injection. Nanoparticle size (intensity distribution) was measured using a Zetasizer Nano (Malvern). $\zeta$ (zeta)-potential was measured with the Zetasizer by diluting $20 \mu \mathrm{L}$ of $1 \mathrm{mg} / \mathrm{ml}$ particle PBS solution in $1 \mathrm{~mL}$ of double distilled water. For nanoparticle imaging with transmission electron microscopy, the nanoparticle solution in water was placed on Formvar-/carbon-coated grids (Ted Pella). After 5 minutes, the grid was gently blotted and air dried. The samples were studied without counterstaining. Grids were viewed using a JEOL 1200EX II transmission electron microscope at $75 \mathrm{kV}$ and different instrumental magnifications. Images were captured using a Gatan digital camera.

\section{In vitro nanoparticle uptake experiments}

Full-length mouse cDNA of SR-AI (splicing variant A, NM_001113326) was amplified from mouse liver mRNA by reverse transcription polymerase chain reaction using the following primers:

Forward:

GCAGTCGGATCCATGACAAAAGAGATGA CAGAGAATC

Reverse:

GCAGTCCTCGAGTTATGAAGTACAAGTG ACCCCAG.

The amplified cDNA was subsequently cloned into pcDNA 3.1+ Zeo plasmid (Life Technologies) using the BamHI and XhoI restriction sites. Human embryonic kidney cells HEK293T were maintained in Dulbecco's Modified Eagle Medium (DMEM)/high glucose media (Hyclone) supplemented with 10\% fetal bovine serum (FBS) and $1 \%$ penicillinstreptomycin-L-glutamine solution). For transfection experiments, cells were seeded at a 
density of $0.5-1 \times 10^{6}$ cells/well in 24-well plates and transiently transfected with $0.5 \mu \mathrm{g}$ of receptor plasmids or empty vector pcDNA 3.1 using Lipofectamine 2000 (Life Technologies) as per the manufacturer's instructions. The expression on the cell surface was tested by immunostaining with rat-anti mouse SR-AI/II antibody (R\&D Systems).

Fresh KCs were isolated from mice by intraportal collagenase perfusion and differential centrifugation over Percoll (Sigma) gradient as previously described. ${ }^{20}$ This protocol results in isolation of relatively pure and fully functional $\mathrm{KCs}^{21}$ In order to assess the purity of KCs after isolation, mice were injected 10 minutes prior to perfusion with $100-\mu \mathrm{g}$ carbon ink nanoparticles (Sigma). Over $80 \%$ of the isolated cells were labeled with carbon ink. Nanoparticle uptake quantification in receptor-transfected cells and KCs was performed as described elsewhere. ${ }^{14}$ The experiments were performed on the same day of the isolation. Briefly, the cells were incubated with $0.1 \mathrm{mg} / \mathrm{mL}$ (Fe concentration) for 2 hours in $10 \%$ FBS-supplemented medium at $37^{\circ} \mathrm{C}$. At the end of the incubation, the cells were washed 2 times with serum-free DMEM followed once with phosphate buffer saline (PBS) and subsequently lysed with $10 \%$ SDS; iron uptake was quantified using ferrozine assay. ${ }^{22}$ For the ligand inhibition experiment, polyinosinic acid (PIA) $(10 \mu \mathrm{g} / \mathrm{mL})$, heparin $(10 \mu \mathrm{g} / \mathrm{mL})$, heparan sulfate $(50 \mu \mathrm{g} / \mathrm{mL})$, or chondroitin sulfate $(50$ $\mu \mathrm{g} / \mathrm{mL}$ ) were added to cells for 15 minutes prior to nanoparticles.

\section{In vivo clearance and liver uptake in mice}

All of the animal studies described in this paper were reviewed and approved by UC San Diego and UC Denver IACUC. For studies involving SPIO uptake in normal mice, C57BL/6J female mice were used. Scavenger receptor AI/II-deficient mice (B6.Cg$\left.M s r I^{t m l C s k} / \mathrm{J}\right)$ were obtained from Jax Mice. Eightto twelve-week-old female mice were used for the experiments. Age- and gender-matched control C57BL/6J mice were purchased from the same vendor. Nanoparticles $(4 \mathrm{mg} \mathrm{Fe} / \mathrm{kg}$ body weight) were injected into the tail vein in a total volume of $100 \mu \mathrm{L}$. Blood was collected from the periorbital vein by heparinized capillaries at different time points, and plasma was separated from cells by centrifugation at $5,000 \mathrm{rpm}$ for 2 minutes. Ten microliters of plasma were collected to measure iron levels by ferrozine assay, and the elimination half-life was determined using Prism (GraphPad) software by fitting the percentage of $\mathrm{Fe}$ in blood over time into a monoexponential decay curve.

For histological analysis of nanoparticle uptake, animals were sacrificed 4 hours postinjection with perfusion, and livers were dissected, fixed in formalin, cryosectioned, and stained for iron accumulation using Prussian blue stain and nuclear fast red (counterstain). In some of the experiments, mice were pre-injected with carbon ink in order to identify $\mathrm{KCs}$ in the sections.

To test the effects of polyanions on nanoparticle clearance, C57BL/6 female mice were pre-injected with PIA intravenously (25 $\mathrm{mg} / \mathrm{kg})$ and intraperitoneally $(12.5 \mathrm{mg} / \mathrm{kg})$ before injection of nanoparticles. Ten minutes after injection of nanoparticles, mice were injected intravenously with another bolus of PIA (12.5 $\mathrm{mg} / \mathrm{kg}$ ).

\section{Results}

\section{In vitro experiments}

In order to investigate the role of SR-AI/II in vivo, we used SPIO nanoparticle Feridex coated with a linear T-10 $(10 \mathrm{kDa})$ dextran and SPIO nanoworms coated with a branched $20 \mathrm{kDa}$ dextran (Figure 1A). Transmission electron microscopy images showed that Feridex and SPIO NWs appeared as clusters of $\sim 7 \mathrm{~nm}$ electron-dense iron oxide crystals (Figure 1A). Feridex magnetic cores are clustered, whereas SPIO NWs have an elongated worm-like shape (Figure 1A). The shell of SPIO NWs (not visible on transmission electron microscope) is apparently thicker due to longer dextran chains, and iron crystals have better coverage. ${ }^{11,23}$ DLS and zeta potential measurements showed Feridex and SPIO NW had hydrodynamic diameters around $100 \mathrm{~nm}$ (Figure 1B). Feridex was slightly more negative $(-12 \mathrm{mV})$ than SPIO NWs $(-6 \mathrm{mV})$ (Figure 1C). 
A

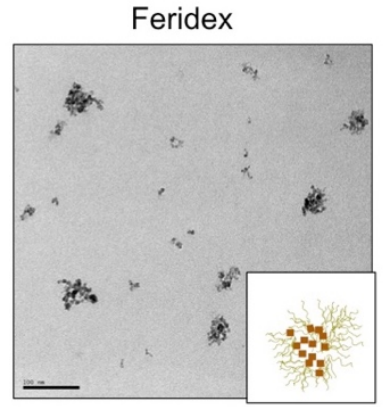

B

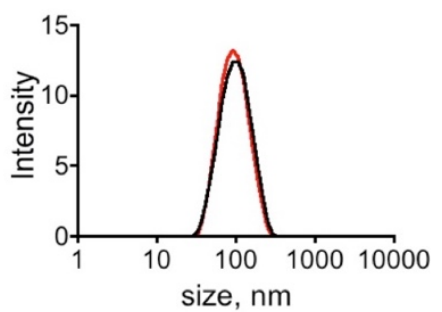

SPIO NW

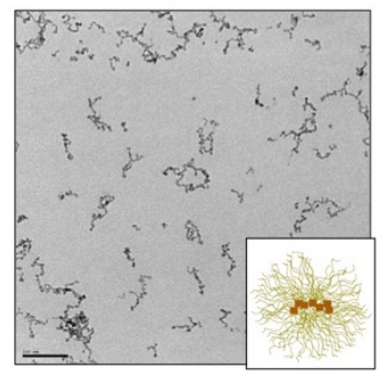

C

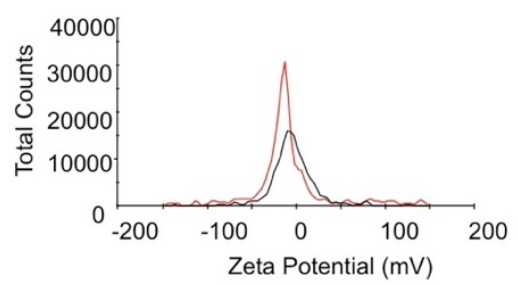

Figure 1. Size, zeta potential and TEM analysis of nanoparticles. A, TEM images (iron oxide cores) and schematic representation (inserts) of nanoparticles used in the study. Size bar, $100 \mathrm{~nm}$; B, Size (intensity distribution); C, zeta potential. Red line-Feridex; black line-SPIO NWs. SPIO = superparamagnetic iron oxide; TEM = transmission electron microscopy.

To test the role of SR-AI/II in the uptake of Feridex and SPIO NWs, we transfected HEK293T cells with a plasmid coding for SR-
AI. ${ }^{12}$ SR-AI is structurally similar to SR-AII and is a transcriptional variant with nearly identical specificity. $^{24}$

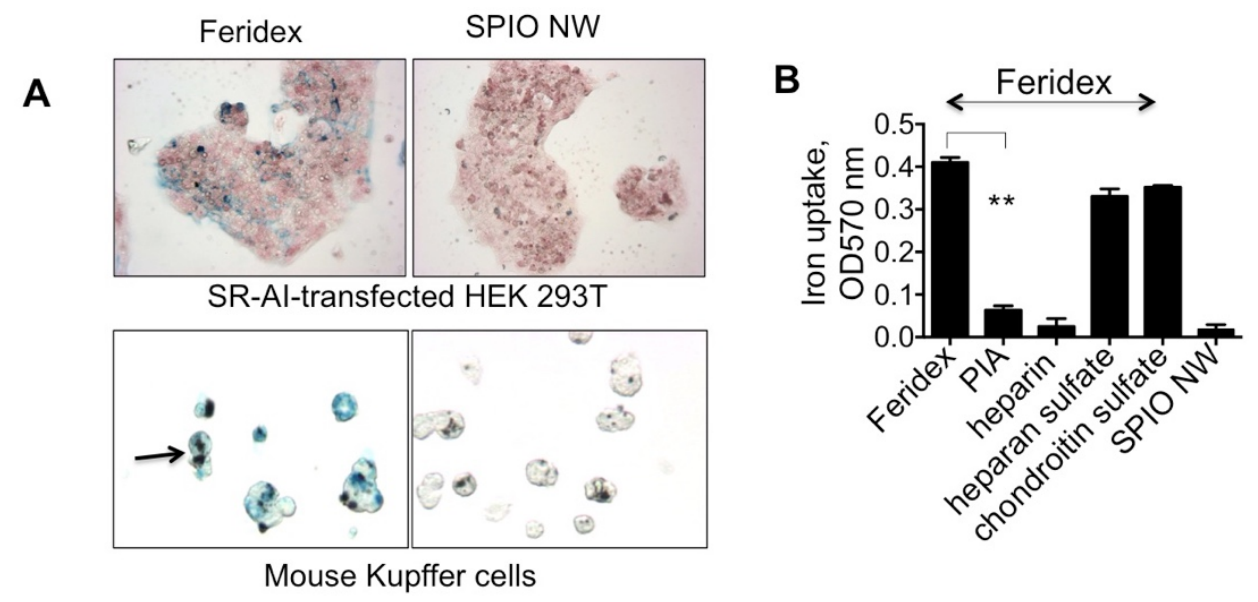

Figure 2. Binding and uptake via SRs A, Top, uptake of Feridex and SPIO NWs by HEK293T cells transiently transfected with SR-AI plasmid as described in Methods. Iron uptake was visualized with Prussian blue, and nuclei were counterstained with Nuclear fast red. The cells were imaged with a 10x objective; Bottom, uptake of Feridex and SPIO NWs by freshly isolated KCs. Mice were preinjected with carbon ink to label KCS (arrow); B) Uptake of nanoparticles by KC in presence of SR-Al/II inhibitors (heparin and PIA). Heparan sulfate and chondroitin sulfate are polyanions but are not potent SR inhibitors. The uptake was quantified with iron assay. Note an almost non-detectable uptake of SPIO NWs. ( $n=3$, two-sided non-paired t-test). KC = Kupffer cells; SPIO = superparamagnetic iron oxide; PIA = polyinosinic acid.. 
After a one-hour incubation of Feridex and SPIO NWs with transfected cells followed by washing and Prussian blue staining, there was efficient uptake of Feridex but no visible uptake of SPIO NWs (Figure 2A).
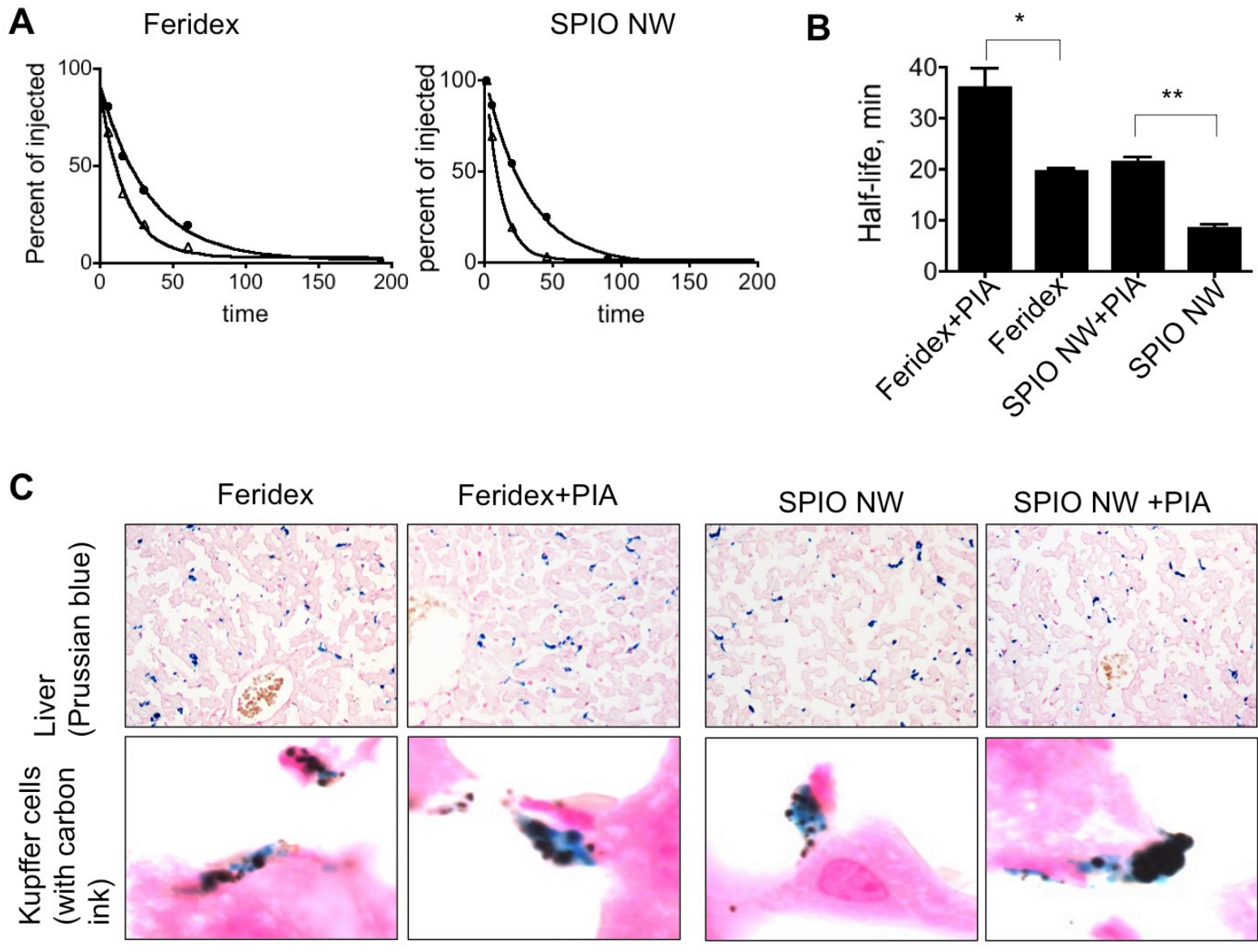

Figure 3. Effect of PIA on the clearance and uptake by Kupffer cells Mice were pre-injected with either $25 \mathrm{mg} / \mathrm{kg}$ PIA or PBS followed by injection of nanoparticles at $4 \mathrm{mg} / \mathrm{kg}$, and half-life was measured as described in Methods. Two hours post-injection (after nanoparticles cleared from circulation), the mice were sacrificed, and their livers were fixed and stained with Prussian blue/nuclear fast. A, Representative curves of plasma clearance of nanoparticles fitted into monoexponential decay. Filled symbols, with PIA; open symbols, without PIA. PIA prolongs half-life of both Feridex and 20kDa SPIO. B, Calculated half-lives on nanoparticles in circulation (two-sided non-paired t-test, $n=3$ ); $C$, Liver images of mice showing classical uptake pattern of KCs. The uptake was similar regardless of the PIA pretreatment. Bottom panel shows representative cropped images of liver macrophages labeled in vivo by I.V. injection of carbon ink. The macrophages show colocalization of iron oxide (Prussian blue-positive) and carbon ink (black dots). PIA did not prevent the accumulation in $K C S(n=3$, two-sided non-paired $t$-test). KC $=K u p f f e r$ cells; $S P I O=$ superparamagnetic iron oxide; $P B S=$ pyrogen-free water; $P I A=$ polyinosinic acid .

Next, we tested the Feridex and SPIO NW uptake by freshly isolated KCs. KCs were labeled by pre-injecting mice with carbon ink to enable their identification. The uptake experiments were performed in $10 \%$ FBS-supplemented serum, a standard serum condition for testing of nanoparticle uptake in many studies. There was efficient uptake of Feridex and almost no uptake of SPIO NWs (Figure 2A, lower panel). Next we tested the uptake of Feridex and SPIO NW by $\mathrm{KCs}$ in the presence of SR polyanion inhibitors reported to be potent competitors of SRs. ${ }^{24}$ SR$\mathrm{AI} / \mathrm{II}$ exhibits a specificity of inhibition to polyanions: PIA and heparin are effective inhibitors, whereas DNA, poly-A, heparan sulfate, and chondroitin sulfate are not effective 
inhibitors. This is related to structural requirements for binding of polyanions to the collagen-like domain of SR-AI/II. ${ }^{3,24}$ Feridex uptake was effectively inhibited by addition of 10 $\mu \mathrm{g} / \mathrm{mL}$ PIA or $10 \mu \mathrm{g} / \mathrm{mL}$ heparin, but not by 50 $\mu \mathrm{g} / \mathrm{mL}$ heparan sulfate or $50 \mu \mathrm{g} / \mathrm{mL}$ chondroitin sulfate (Figure 2B). Such selectivity of the polyanionic inhibitors is characteristic of SRAI/II-mediated uptake. ${ }^{24}$ Under the same conditions the uptake of SPIO NWs was undetectable.

\section{In vivo experiments}

In the subsequent set of in vivo experiments, we tested the contribution of SR-AI/II to the clearance of Feridex and SPIO NW by KCs. Following intravenous injection Feridex was cleared from the blood with a half-life of about 20 minutes (Figure $3 \mathrm{~A}$ and $\mathrm{B}$ ) and the particles were localized in $\mathrm{KCs}$ in the liver (Figure 3C). Injection of PIA $(\sim 150 \mu \mathrm{g} / \mathrm{mL}$ blood $)$ extended the circulation half-life of Feridex to 37 minutes (Figure $3 \mathrm{~A}$ and $\mathrm{B}$ ) but did not change the localization of nanoparticles in KCs (Figure 3C). In contrast to in vitro experiments where SPIO NWs were not internalized by KCs, SPIO NWs were cleared in vivo with a half-life of $\sim 10 \mathrm{~min}$ (Figure 3A and $\mathrm{B}$ ) and the particles were sequestered in KCs in the liver (Figure 3C). Preinjection of PIA extended the half-life of SPIO NWs to 20 minutes but did not visibly affect the accumulation of in the liver KCs (Figure 3C).

In order to test whether the effect of PIA on blood half-life was due to the inhibition of SRA/II-mediated uptake, we compared circulation properties and KC uptake of Feridex and SPIO NW after injection into wild type and SR-AI/II knockout mice. Elimination from blood of Feridex and SPIO NWs was not affected in the SR-AI/II knockout mice (Figure 4A) and the accumulation of Feridex and SPIO NW in the $\mathrm{KCs}$ in vivo was not altered (Figure 4B). This experiment excludes the possibility that PIA dose was insufficient in order to block SR-AI/IImediated uptake and suggests that PIA prolonged blood circulation via other mechanisms that were more specific for in vivo system.
A

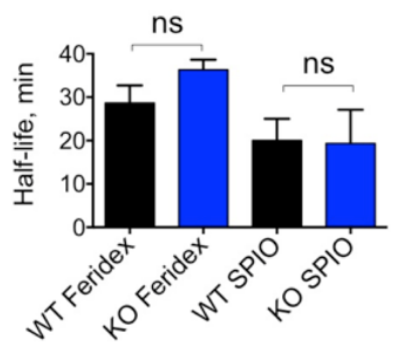

B

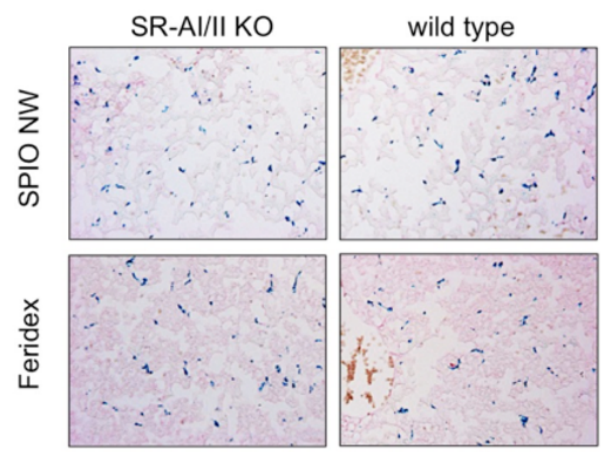

Figure 4. Effect of SR-AI/II deficiency on clearance of SPIO. Animals deficient for SR-AI/II and wild-type controls (in C67/BL6 background) were injected with Feridex or SPIO $N W s$, and the half-life was determined as described in Methods; A, Calculated plasma half-life of Feridex and SPIO NWs. Note that there was only marginal increase in the halflife in knockout mice that was not statistically significant at the sample size of 3; B, Liver uptake of Feridex and SPIO NWs. Knockout liver shows similar KC mediated uptake compared to wild-type animals ( $n=3$, two-sided non-paired $t$-test). $K C=$ Kupffer cells; SPIO = superparamagnetic iron oxide

\section{Discussion}

Nanoparticle clearance is a complex process mediated by a combination of plasma opsonins, macrophage receptors, ${ }^{25}$ nanoparticle coating, size, and charge. ${ }^{26,27}$ In accordance with our previous studies, ${ }^{10}$ SR-AI overexpressed on HEK293T cells was capable of internalizing $10 \mathrm{kDa}$ coated SPIO Feridex but not $20 \mathrm{kDa}$ dextran-coated SPIO NWs. SR-AII, a splicing variant of SR-AI, showed efficient uptake of Feridex in our previous work. ${ }^{11}$ Fresh isolated KCs showed potent uptake of Feridex but not of SPIO NWs, and the SR inhibitors PIA and heparin inhibited the uptake of the former. These data point to the significant role of SRs in the in vitro uptake of Feridex by KCs.

However, our in vivo study demonstrated a discrepancy from in vitro experiments. Thus, (1) 
PIA at $10 \mu \mathrm{g} / \mathrm{mL}$ serum completely blocked the uptake of Feridex in vitro, but at $\sim 150 \mu \mathrm{g} / \mathrm{mL}$ blood did not affect $\mathrm{KC}$ clearance in vivo; (2) there was a marginal effect of SR-A/II deficiency (knockout mice experiment) on KCs uptake of Feridex in vivo; (3) Feridex and SPIO NWs showed differences in the uptake in vitro but similar uptake by KCs in vivo.

The experiments above suggest that SR-AI/II is not the major receptor mediating clearance of nanoparticles in vivo, but do not exclude the role of other SRs (Figure 5).

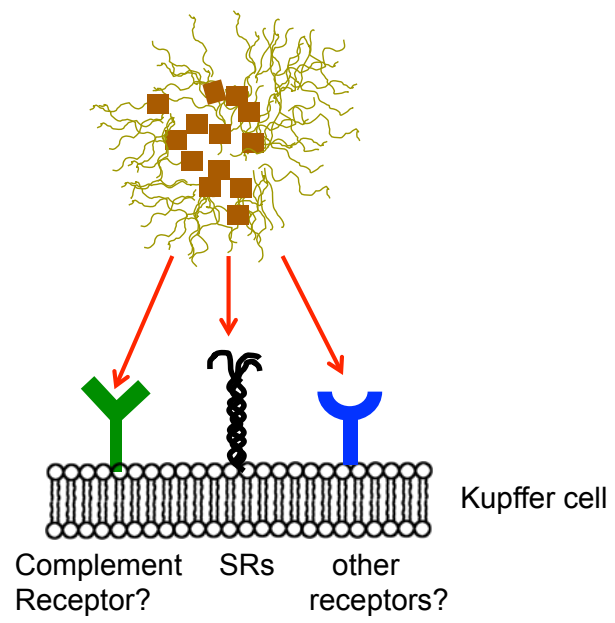

Figure 5. Redundant uptake of Feridex and SPIO NWs by Kupffer cells. The uptake could be mediated by a combination of SRs, complement receptors and other immune receptors, with and without opsonin involvement. $S P I O=$ superparamagnetic iron oxide; $S R=$ scavenger receptor.

It has been reported that SR-AI/II knockout only partially prevents the clearance of pathogens, damaged cells, and particles,${ }^{28-30}$ and that even double scavenger receptor knockouts did not completely prevent in vivo clearance. ${ }^{28,31}$ It was suggested that multiple SRs could duplicate one another's function in vivo, therefore necessitating multiple scavenger receptor knockouts. ${ }^{28,31}$ Another study demonstrated a strong effect of fucoidan, a polysulfated carbohydrate, on in vivo clearance of iron oxide nanoparticles. ${ }^{32}$ Indeed, fucoidan is a broad inhibitor that blocks uptake via multiple classes of SRs (e.g., MARCO, PSOX, collectins, and LOX-1). ${ }^{12,33}$ Adding to this complexity, polyanions interact with plasma and cell proteins, including complement, clotting factors, lipoproteins, and phospholipids. ${ }^{34-37}$

\section{Limitations of the study}

Among limitations of our study is that in vitro experiments used 10\% FBS, which does not resemble the in vivo milieu. Of all mechanisms that could synergize with SRs, complement is considered one of the main triggers of nanoparticle clearance. ${ }^{38}$ Complement is not completely functional in FBS. We previously demonstrated that both Feridex and SPIO NWs potently activate complement in mouse and human serum and plasma. ${ }^{39}$ PIA showed some prolongation of circulation half-life in vivo. As the pathways of complement activation of SPIO usually converge on the alternative pathway, ${ }^{23}$ which involves recognition of anionic surface by properdin, ${ }^{40}$ it would be interesting to understand the effect of polyanions on complement convertase assembly. Polyanions can also displace surface-bound complement factors, such as $\mathrm{Clq}$, from nanoparticle surface. ${ }^{41}$ Another limitation of the study is that KCs are taken out of the liver tissue context. Several classical studies used in situ liver perfusion in order to understand role of plasma proteins in uptake of nanoparticles ${ }^{42,43}$; such studies could be a better alternative to in vitro experiments. However, perfusion experiments are challenging and are not high throughput, so in vitro studies are still the mainstream research tool for many labs.

\section{Conclusion}

In conclusion, based on our data, the involvement of multiple redundant pathways in $\mathrm{KC}$ capture of nanoparticles cannot be excluded. For example, KC-associated complement receptors, ${ }^{44}$ non-SR-AI/II scavenger receptors, and yet to be identified pathways, may be involved. These studies are in line with studies on pathogens, where effect of single pathway knockout failed to demonstrate the effect. The study demonstrates an interesting discrepancy between the in vitro and in vivo role of scavenge receptors and also necessitates further investigation of molecular mechanisms of nanoparticle clearance. 


\section{Conflict of interest}

The authors have no relevant financial or non-financial interests to disclose. For signed statements contact the journal office editor@precisionnanomedicine.com.

Quote this article as Wang G, Groman E, Simberg D., Discrepancies in the in vitro and in vivo role of scavenger receptors in clearance of nanoparticles by Kupffer cells. Precis. Nanomed. 2018;1(1):76-84, https://doi.org/10.29016/180430.1

\section{References}

(1) Taylor, P. R.; Martinez-Pomares, L.; Stacey, M.; Lin, H. H.; Brown, G. D.; Gordon, S. Annual review of immunology 2005, 23, 901-944.

(2) Sadauskas, E.; Wallin, H.; Stoltenberg, M.; Vogel, U.; Doering, P.; Larsen, A.; Danscher, G. Particle and fibre toxicology 2007, 4, 10.

(3) Doi, T.; Higashino, K.; Kurihara, Y.; Wada, Y.; Miyazaki, T.; Nakamura, H.; Uesugi, S.; Imanishi, T.; Kawabe, Y.; Itakura, H.; et al. J Biol Chem 1993, 268, 2126-2133.

(4) Kanno, S.; Furuyama, A.; Hirano, S. Toxicological sciences : an official journal of the Society of Toxicology 2007, 97, 398-406.

(5) Nagayama, S.; Ogawara, K.; Minato, K.; Fukuoka, Y.; Takakura, Y.; Hashida, M.; Higaki, K.; Kimura, T. International journal of pharmaceutics 2007, 329, 192-198. $56-63$

(6) Raynal, I.; Prigent, P.; Peyramaure, S.; Najid, A.; Rebuzzi, C.; Corot, C. Invest Radiol 2004, 39,

(7) Zhang, L. W.; Monteiro-Riviere, N. A. Toxicological sciences : an official journal of the Society of Toxicology 2009, 110, 138-155.

(8) Kobzik, L. Journal of immunology 1995, 155, 367-376.

(9) Patel, P. C.; Giljohann, D. A.; Daniel, W. L.; Zheng, D.; Prigodich, A. E.; Mirkin, C. A. Bioconjugate chemistry 2010, 21, 2250-2256.

(10) Lunov, O.; Zablotskii, V.; Syrovets, T.; Rocker, C.; Tron, K.; Nienhaus, G. U.; Simmet, T. Biomaterials 2011, 32, 547-555.

(11) Chao, Y.; Karmali, P. P.; Mukthavaram, R.; Kesari, S.; Kouznetsova, V. L.; Tsigelny, I. F.; Simberg, D. ACS Nano 2013, 7, 4289-4298.

(12) Chao, Y.; Makale, M.; Karmali, P. P.; Sharikov, Y.; Tsigelny, I.; Merkulov, S.; Kesari, S.; Wrasidlo, W.; Ruoslahti, E.; Simberg, D. Bioconjugate chemistry 2012, 23, 1003-1009.

(13) Chao, Y.; Karmali, P. P.; Simberg, D. Advances in experimental medicine and biology 2012, 733, $115-123$.

(14) Simberg, D.; Park, J. H.; Karmali, P. P.; Zhang, W. M.; Merkulov, S.; McCrae, K.; Bhatia, S. N.; Sailor, M.; Ruoslahti, E. Biomaterials 2009, 30, 3926-3933.

(15) Bulte, J. W.; Kraitchman, D. L. NMR Biomed 2004, 17, 484-499.

(16) Simberg, D.; Duza, T.; Park, J. H.; Essler, M.; Pilch, J.; Zhang, L.; Derfus, A. M.; Yang, M.; Hoffman, R. M.; Bhatia, S.; Sailor, M. J.; Ruoslahti, E. Proceedings of the National Academy of Sciences of the United States of America 2007, 104, 932-936.

(17) Jung, C. W. Magn Reson Imaging 1995, 13, 675-691.

(18) Jung, C. W.; Jacobs, P. Magn Reson Imaging 1995, 13, 661-674.

(19) Park, J. H.; von Maltzahn, G.; Zhang, L.; Schwartz, M. P.; Ruoslahti, E.; Bhatia, S.; Sailor, M. J. Advanced materials 2008, 20, 1630-1635.

(20) Froh, M.; Konno, A.; Thurman, R. G. Curr Protoc Toxicol 2003, Chapter 14, Unit14 14. 
(21) Movita, D.; Kreefft, K.; Biesta, P.; van Oudenaren, A.; Leenen, P. J.; Janssen, H. L.; Boonstra, A. Journal of leukocyte biology 2012, 92, 723-733.

(22) Riemer, J.; Hoepken, H. H.; Czerwinska, H.; Robinson, S. R.; Dringen, R. Analytical biochemistry 2004, 331, 370-375.

(23) Chen, F.; Wang, G.; Griffin, J. I.; Brenneman, B.; Banda, N. K.; Holers, V. M.; Backos, D. S.; Wu, L.; Moghimi, S. M.; Simberg, D. Nature nanotechnology 2017, 12, 387-393.

(24) Platt, N.; Gordon, S. Chem Biol 1998, 5, R193-203.

(25) Karmali, P. P.; Simberg, D. Expert Opin Drug Deliv 2011, 8, 343-357.

(26) Moghimi, S. M.; Hunter, A. C.; Murray, J. C. Pharmacological reviews 2001, 53, 283-318.

(27) Li, S. D.; Huang, L. Molecular pharmaceutics 2008, 5, 496-504.

(28) Zhou, H.; Imrich, A.; Kobzik, L. Particle and fibre toxicology 2008, 5, 7.

(29) Terpstra, V.; Kondratenko, N.; Steinberg, D. Proceedings of the National Academy of Sciences of the United States of America 1997, 94, 8127-8131.

(30) Adachi, H.; Tsujimoto, M.; Arai, H.; Inoue, K. J Biol Chem 1997, 272, 31217-31220.

(31) Aslanian, A. M.; Charo, I. F. Circulation 2006, 114, 583-590.

(32) Abdollah, M. R. A.; Carter, T. J.; Jones, C.; Kalber, T. L.; Rajkumar, V.; Tolner, B.; Gruettner, C.; Zaw-Thin, M.; Baguna Torres, J.; Ellis, M.; Robson, M.; Pedley, R. B.; Mulholland, P.; R, T. M. d. R.; Chester, K. A. ACS Nano 2018, 12, 1156-1169.

(33) Wang, G.; Simberg, D. Reviews in Cell Biology and Molecular Medicine 2015, 1, 166-189.

(34) Vandergraaf, F.; Koedam, J. A.; Bouma, B. N. Journal of Clinical Investigation 1983, 71, 149158.

(35) Kim, Y. C.; Nishida, T. J Biol Chem 1979, 254, 9621-9626.

(36) Huster, D.; Arnold, K. Biophys J 1998, 75, 909-916.

(37) Hughes-Jones, N. C.; Gardner, B. Immunology 1978, 34, 459-463.

(38) Andersen, A. J.; Hashemi, S. H.; Andresen, T. L.; Hunter, A. C.; Moghimi, S. M. J Biomed Nanotechnol 2009, 5, 364-372.

(39) Banda, N. K.; Mehta, G.; Chao, Y.; Wang, G.; Inturi, S.; Fossati-Jimack, L.; Botto, M.; Wu, L.; Moghimi, S.; Simberg, D. Particle and fibre toxicology 2014, 11, 64.

(40) Spitzer, D.; Mitchell, L. M.; Atkinson, J. P.; Hourcade, D. E. Journal of immunology 2007, 179, 2600-2608.

(41) Acton, S.; Resnick, D.; Freeman, M.; Ekkel, Y.; Ashkenas, J.; Krieger, M. J Biol Chem 1993, 268 , $3530-3537$.

(42) Kiwada, H.; Matsuo, H.; Harashima, H. Advanced drug delivery reviews 1998, 32, 61-79.

(43) Furumoto, K.; Ogawara, K.; Nagayama, S.; Takakura, Y.; Hashida, M.; Higaki, K.; Kimura, T. J Control Release 2002, 83, 89-96.

(44) Helmy, K. Y.; Katschke, K. J., Jr.; Gorgani, N. N.; Kljavin, N. M.; Elliott, J. M.; Diehl, L.; Scales, S. J.; Ghilardi, N.; van Lookeren Campagne, M. Cell 2006, 124, 915-927. 